\title{
PENERAPAN MODEL PEMBELAJARAN INVESTIGASI KELOMPOK MELALUI MEDIA DOMINO MATEMATIKA UNTUK MENINGKATKAN KEMAMPUAN BERPIKIR KRITIS SISWA
}

\author{
Cut Yuniza Eviyanti ${ }^{1}$, Lia Rista ${ }^{2}$, Siti Hadijah ${ }^{3}$ \\ ${ }^{1,2,3}$ Pendidikan Matematika, STKIP Bumi Persada Lhokseumawe, Indonesia \\ eviyanticut@yahoo.co.id
}

\begin{abstract}
This research aims to know the improvement of students 'critical thinking skills through the application of the group investigative learning model through domino mathematics (domat) media which is better than increasing students' critical thinking skills through the application of conventional learning. This research was a quasi experimental study with pretest-postest randomized control group design. The research sample was determined by a random technique which became the experimental class $\left(\mathrm{IX}_{\mathrm{A}}\right)$ and the control class $\left(\mathrm{IX}_{\mathrm{B}}\right)$. The results of testing the N-Gain data on students' critical thinking skills showed that the data were normally distributed and homogeneous, so that it could be analyzed with the one-side t-test statistic at the significant level $\alpha=0.05$. Based on the results of data processing on the N-Gain score of students 'critical thinking skills, it was obtained $t$ Count $=4.05$ and $\mathrm{t}_{\text {Table }}=1.71$ or $4.05>1.71$, this means that $\mathrm{H}_{0}$ was rejected, so it can be concluded that the increase in students' critical thinking skills who got application with the learning model Group investigations through domat media are better than the students who got conventional learning on exponential numbers and root forms.
\end{abstract}

Keywords: Group Investigation Learning, Critical Thinking Ability, Mathematical Dominoes, Exponential Numbers and Root Forms.

\begin{abstract}
Abstrak
Penelitian ini bertujuan untuk mengetahui peningkatkan kemampuan berpikir kritis siswa melalui penerapan model pembelajaran investigasi kelompok melalui media domino matematika (domat) lebih baik dibandingkan peningkatkan kemampuan berpikir kritis siswa melalui penerapan pembelajaran konvensional. Penelitian yang dilakukan merupakan penelitian quasi eksperimen dengan desain randomized control group pretest-postest. Sampel penelitian ditentukan dengan teknik acak yang menjadi kelas eksperimen (IX $\left.{ }_{\mathrm{A}}\right)$ dan kelas kontrol $\left(\mathrm{IX}_{\mathrm{B}}\right.$ ). Hasil pengujian data $\mathrm{N}$-Gain kemampuan berpikir kritis siswa menunjukkan bahwa data berdistribusi normal dan homogen, sehingga dapat dianalisis dengan statistik uji-t satu pihak pada taraf signifikan $\alpha=0.05$. Berdasarkan hasil pengolahan data terhadap $N$-Gain skor kemampuan berpikir kritis siswa diperoleh $\mathrm{t}_{\mathrm{Hitung}}=$ 4.05 dan $\mathrm{t}$ Tabel $=1.71$ atau $\mathrm{t}_{\text {Hitung }}>\mathrm{t}_{\text {Tabel }}$ yaitu 4.05>1.71, hal ini berarti $\mathrm{H}_{0}$ ditolak, sehingga dapat disimpulkan bahwa peningkatan kemampuan berpikir kritis siswa yang mendapat penerapan dengan model pembelajaran investigasi kelompok melalui media domat lebih baik dari siswa yang mendapat pembelajaran konvensional pada materi bilangan berpangkat dan bentuk akar.
\end{abstract}

Kata Kunci: Pembelajaran Investigasi Kelompok, Kemampuan Berpikir Kritis, Domino Matematika, Bilangan Berpangkat dan Bentuk Akar

\section{PENDAHULUAN}

Pembelajaran matematika memiliki fungsi sebagai sarana untuk mengembangkan kemampuan berpikir kritis, logis dan kreatif. Proses berpikir dalam pemecahan masalah matematika memerlukan kemampuan intelektual. Hal itu tentu saja akan melatih siswa untuk berpikir kritis, logis dan kreatif. Bilangan berpangkat dan bentuk akar merupakan salah satu materi sulit dalam mata pelajaran matematika, salah satunya bagi siswa di SMP Negeri 1 Lhokseumawe. Hal ini terlihat dari rendahnya hasil ulangan pada materi tersebut, hanya 16 orang siswa dari 145 orang siswa yang mendapat nilai 75 dan diatasnya, sisanya mendapat nilai dibawah 75 . Temuan ini semakin diperkuat dengan rendahnya 
hasil tes kemampuan berpikir kritis siswa yang diberikan peniliti saat observasi. Tidak ada siswa yang berhasil menyelesaikan soal dengan lengkap dan benar. Hal ini dapat dilihat dari gambar 1 dibawah.

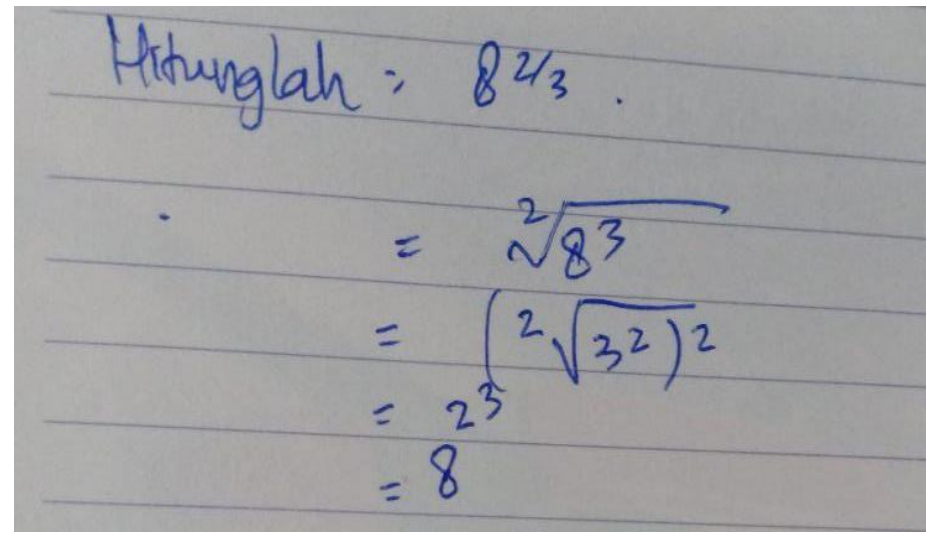

Gambar 1. Salah satu hasil jawaban siswa.

Jawaban yang dikemukakan pada gambar 1 diatas memiliki kesalahan yang mendasar di karenakan siswa belum memahami konsep bilangan berpangkat dan bentuk akar sehingga proses jawaban siswa belum mengarah pada jawaban yang sesuai. Bilangan berpangkat dan bentuk akar sangat penting dalam kehidupan sehari-hari. Jadi penguasaan materi bilangan berpangkat dan bentuk akar sangat penting bagi siswa, karena itu pemahaman bilangan berpangkat dan bentuk akar perlu ditekankan sedini mungkin pada siswa. Kemajuan ilmu pengetahuan akan mempengaruhi cara belajar yang efektif, sehingga perlu adanya cara berpikir secara terarah dan jelas. Oleh karenanya kemampuan berpikir kritis sangat penting bagi siswa.

Kemampuan berpikir kritis dapat terlaksana jika guru menerapkan cara belajar kepada siswa dengan belajar penyelidikan. Dimana cara belajar yang seperti itu dapat menjadikan siswa lebih kritis dalam memahami suatu permasalahan yang di dapat. (Suwarna, 2019) mengatakan,"kemampuan berpikir kritis merupakan kemampuan untuk ikut serta dalam kegiatan, proses, atau prosedur umum untuk mengerjakan sesuatu dengan benar dalam waktu yang tepat”. Sedangkan (Lloyd, M. Bahr, 2010) mengatakan,'berpikir kritis merupakan tujuan penting pendidikan di sekolah". Dari beberapa pendapat tersebut dapat dipahami bahwa berpikir kritis adalah keharusan dalam pemecahan masalah, pembuatan keputusan, sebagai pendekatan, menganalisis asumsi-asumsi dan penemuan-penemuan. Berpikir kritis diterapkan siswa untuk belajar memecahkan masalah secara sistematis dalam menghadapi tantangan. Kemampuan berpikir kritis dapat di perkuat melalui media domat dalam pembelajaran sehingga pembelajaran tidak membosankan. Model dalam pembelajaran juga sangat menentukan berhasil tidaknya pencapaian hasil belajar yang baik.

(Suprihatiningrum, 2013) mengatakan, "Model pembelajaran merupakan pola yang telah direncanakan dengan matang dan merupakan pedoman pelaksanaan pembelajaran mulai dari pembukaan, inti, dan penutup serta penilaian pembelajaran yang disusun sedemikian rupa untuk mencapai tujuan pembelajaran". Keberhasilan proses pembelajaran tidak terlepas dari kemampuan 
guru menerapkan model-model pembelajaran yang berorientasi pada peningkatan intensitas keterlibatan siswa secara efektif di dalam proses pembelajaran (Anggraini et al., 2010). Jadi, pertimbangan utama model pembelajaran ialah tujuan pengajaran yang ingin dicapai. Menurut Slavin (Rusman, 2010) mengatakan,"pembelajaran kooperatif menggalakkan siswa berinteraksi secara aktif dan positif dalam kelompok". Dalam model pembelajaran kooperatif ini, guru lebih berperan sebagai fasilitator. Pembelajaran kooperatif merupakan salah satu model pembelajaran yang berbasis kontruktivis.

Salah satu model pembelajaran kooperatif tipe investigasi kelompok sangat tepat digunakan untuk pelajaran matematika yang menekankan siswa untuk menyelidiki satu konsep dari topik yang dipelajari. (Wulandari et al., 2016) mengatakan,"Model pembelajaran investigasi kelompok menekankan proses pembentukan pengetahuan secara aktif oleh peserta didik". Investigasi kelompok merupakan salah satu model pembelajaran kooperatif yang memberikan kemungkinan siswa untuk mampu berpikir kritis melalui berbagai kegiatan dari hasil penyelidikan. Salah satu kegiatan tersebut yaitu dengan menggunakan media domat. Pada model ini guru hanya bertindak sebagai fasilitator. Model pembelajaran investigasi kelompok dapat dipakai guru untuk meningkatkan pola berpikir kritis siswa, baik secara perorangan maupun kelompok. (Sumarmi, 2012) mengatakan,"Group Investigation merupakan pembelajaran kooperatif yang melibatkan kelompok kecil, siswa menggunakan inkuiri kooperatif (perencanaan dan diskusi kelompok) kemudian mempresentasikan penemuan mereka di kelas". Model pembelajaran ini dirancang untuk membantu terjadinya pembagian tanggung jawab ketika siswa mengikuti pembelajaran dan berorientasi menuju pembentukan sosial. (Arinda et al., 2019) mengatakan, "model pembelajaran investigasi kelompok membuat siswa lebih aktif dalam melakukan eksperimen dan bertukar ide, selain itu membuat peserta didik belajar dalam situasi kelompok kecil, dimana siswa diberikan tanggung jawab untuk pembelajaran mereka sendiri, sebagaimana siswa lain yang berbeda kelompok".

Pembelajaran konvensional merupakan pembelajaran yang sering digunakan guru pada saat proses pembelajaran berlangsung. Pembelajaran ini berpusat kepada guru dimana guru bertindak sebagai narasumber, informasi disampaikan guru kepada siswa, selanjutnya guru membimbing siswa dalam latihan. Berdasarkan uraian, pendapat, serta data pre research di atas, penulis merasa penting untuk melakukan penelitian dengan mengangkat judul Penerapan Model Pembelajaran Investigasi Kelompok Melalui Media Domat untuk Meningkatkan Kemampuan Berpikir Kritis Siswa di SMP Negeri 1 Lhokseumawe. tujuan penelitian ini adalah untuk mengetahui peningkatkan kemampuan berpikir kritis siswa melalui penerapan model pembelajaran investigasi kelompok lebih baik dibandingkan peningkatkan kemampuan berpikir kritis siswa melalui penerapan pembelajaran konvensional di kelas IX SMP Negeri 1 Lhokseumawe. Bagi siswa, diharapkan dapat meningkatkan kemampuan berpikir kritis siswa terhadap permasalahan matematika secara keseluruhan dan khususnya pada materi bilangan berpangkat dan bentuk akar. Siswa dapat menerima pengalaman belajar lebih bervariasi sehingga dapat meningkatkan motivasi dan hasil belajar pada materi bilangan 
berpangkat dan bentuk akar.

\section{METODE}

Penelitian ini dilaksanakan di SMP Negeri 1 Lhokseumawe. Adapun alasan pemilihan lokasi penelitian ini dikarenakan siswa-siswi SMP ini memiliki kemampuan yang baik dalam hal penyerapan dan penguasaan materi sehingga mempermudah peneliti dalam melakukan penelitian. Populasi pada penelitian ini yakni seluruh siswa/i kelas IX SMP Negeri 1 Lhokseumawe. Sedangkan pengambilan sampel dan penentuan kelas sampel di ambil secara acak, yaitu di ambil 2 kelas, satu kelas sebagai kelas kontrol dan satu kelas sebagai kelas eksperimen. Penelitian ini merupakan suatu studi kuasi eksperimen dengan menggunakan desain penelitian randomized control group pre-test- post-test dengan pola seperti rancangan penelitian pada tabel berikut.

\section{Tabel 1.}

Desain control group pre-test- post-test

\begin{tabular}{|c|c|c|c|}
\hline Subjek & Tes Awal & Perlakuan & Tes Akhir \\
\hline Kelas Eksperimen & $\mathrm{X}_{\mathrm{e}}$ & $\mathrm{A}$ & $\mathrm{Y}_{\mathrm{e}}$ \\
\hline Kelas Kontrol & $\mathrm{X}_{\mathrm{k}}$ & $\mathrm{O}$ & $\mathrm{Y}_{\mathrm{k}}$ \\
\hline
\end{tabular}

Keterangan:

$\mathrm{X}_{\mathrm{e}}$ : tes awal untuk kelas eksperimen

$\mathrm{X}_{\mathrm{k}}$ : tes awal untuk kelas kontrol

$\mathrm{Y}_{\mathrm{e}}$ : tes akhir untuk kelas eksperimen

$\mathrm{Y}_{\mathrm{k}}$ : tes akhir untuk kelas kontol

A : perlakuan dengan menggunakan model pembelajaran investigasi kelompok

$\mathrm{O}$ : perlakuan dengan menggunakan pembelajaran konvensional

\section{Teknik Pengumpulan Data}

Dalam pengumpulan data, instrumen yang digunakan adalah test awal (pre-test) dan tes akhir (post-test). Tes awal yaitu tes yang dilakukan dengan tujuan untuk mengetahui sejauh mana kemampuan awal siswa sebelum pembelajaran diterapkan, sedangkan tes akhir yaitu tes yang dilakukan untuk melihat hasil belajar siswa setelah pembelajaran diterapkan. Soal pre-test dan posttest berupa essay. Peneliti melakukan 5 kali pertemuan, 1 kali pre-test, 3 kali melakukan pembelajaran, namun pembelajaran yang dilakukan secara daring (dalam jaringan) dan 1 kali post-test untuk memperoleh data. Pre-test dan post-test diberikan pada semua siswa kelas eksperimen dan kelas kontrol. Hasil pre-test dan post- test inilah yang digunakan untuk mengetahui peningkatan kemampuan berpikir kritis siswa pada materi bilangan berpangkat dan bentuk akar.

Instrumen penelitian berupa tes kemampuan berpikir kritis yang disusun dan diukur terlebih dahulu tingkat (kriteria) validitasnya sebelum digunakan dalam pengumpulan data, dengan maksud untuk mendapatkan ketepatan data. Hal ini dilakukan untuk memenuhi validitas teoritik instrumen. 


\section{Teknik Analisis Data}

Data yang dianalisis dalam penelitian ini, diperoleh dari tes kemampuan berpikir kritis, tes dilakukan pada awal pembelajaran (sebelum perlakuan), yang disebut sebagai pre-test dan pada akhir pembelajaran (setelah perlakuan), yang disebut post-test. Dari skor pretes dan postes tersebut, dihitung $N$-Gain (gain ternormalisasi). Gain ternormalisasi $(g)$ adalah proporsi antara gain aktual (postespretes) dengan gain maksimal yang dapat dicapai. Selanjutnya, nilai $\mathrm{N}$-Gain inilah yang akan diolah untuk mengetahui besar peningkatan (gain) kemampuan berpikir kritis dengan menggunakan rumus gain ternormalisasi Hake (Eviyanti, 2018) yaitu :

$$
g=\frac{\text { skor posttest }- \text { skor pretest }}{\text { skor maksimal ideal }- \text { skor pretest }}
$$

Dengan kriteria dapat dilihat pada tabel 2 berikut.

\section{Tabel 2.}

\section{Kriteria N-Gain}

\begin{tabular}{|l|c|}
\hline $\mathrm{g} \leq 0,3$ & rendah \\
\hline $0,3<\mathrm{g} \leq 0,7$ & sedang \\
\hline $\mathrm{g}>0,7$ & tinggi \\
\hline
\end{tabular}

Sumber: (Eviyanti, 2018)

Setelah diperoleh nilai gain ternormalisasi, maka perlu dilakukan uji normalitas dan uji homogenitas.

\section{HASIL}

Hasil yang diperoleh dari penelitian yang dilaksanakan di SMP Negeri 1 Lhokseumawe yaitu tentang pelaksanaan pembelajaran pada materi bilangan berpangkat dan bentuk akar dengan menggunakan model pembelajaran investigasi kelompok secara daring melalui media domino matematika (domat) untuk meningkatkan kemampuan berpikir kritis siswa di kelas $\mathrm{IX}_{\mathrm{A}}$ sebagai kelas eksperimen dan kelas $\mathrm{IX}_{\mathrm{B}}$ sebagai kelas kontrol.

Media domat yang digunakan dalam pembelajaran dapat dilihat seperti gambar 2 dibawah ini.

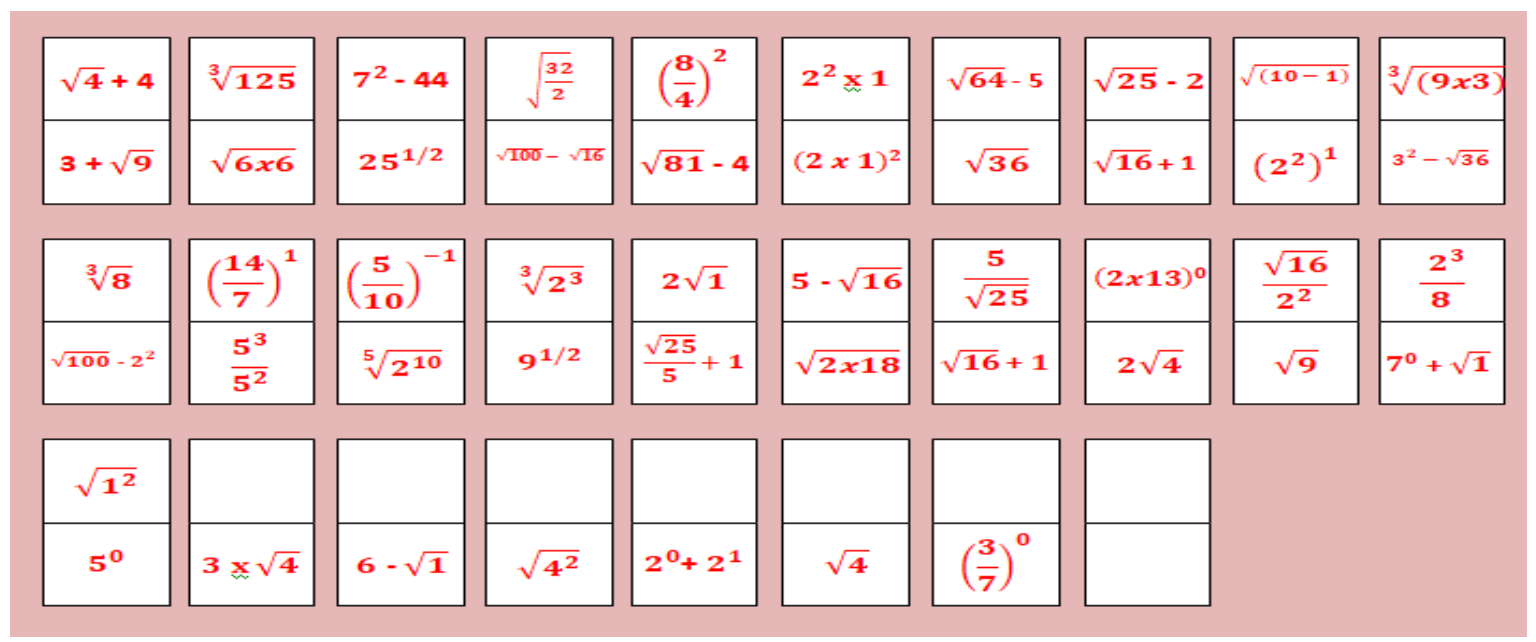

Gambar 2. Media Domino Matematika (Domat) Pada Materi Bilangan Berpangkat dan Bentuk Akar 
Sesuai dengan metode pengolahan data yang telah ditentukan sebelumnya, data akan diolah berdasarkan kriteria yang telah ditetapkan.

\section{Analisis Data Hasil Penelitian}

Hasil perhitungan uji statistik data tes awal dari hasil penelitian yang telah diperoleh. Perhitungan Nilai Rata-rata $(\bar{x})$ kelas eksperimen adalah 44.21 sedangkan Nilai Rata-rata $(\bar{x})$ kelas kontrol adalah 42.79. Dari hasil perhitungan juga diperoleh nilai varians tes awal kelas eksperimen = 33.57 dan nilai simpangan baku tes awal kelas eksperimen $=5.79$. Sedangkan nilai varians tes awal kelas kontrol $=19.57$ dan nilai simpangan baku kelas kontrol $=4.42$.

\section{Uji Normalitas Sebaran Data Tes Awal}

Uji normalitas sebaran data bertujuan untuk mengetahui apakah dari masing-masing kelompok dalam penelitian ini berasal dari populasi berdistribusi normal atau tidak. Penulis menggunakan Uji Lilliefors karena data yang diperoleh tidak disajikan dalam bentuk interval.

Uji Normalitas Sebaran Data Tes Awal Skor Kemampuan Berpikir kritis Siswa Kelas Eksperimen $\left(\mathrm{IX}_{\mathrm{A}}\right)$ diperoleh:
a. $\quad \mathrm{L}_{\text {maks }}=0.1243$
b. Menentukan luas tabel Lilliefors $\left(\mathrm{L}_{\text {tabel }}\right), \mathrm{L}_{\text {tabel }}=\mathrm{L}_{0,05}\left(\mathrm{n}_{1}-1\right)=\mathrm{L}_{0,05}(13)$
$\mathrm{L}_{0.05}(13)=0.234$
c. $\quad \mathrm{L}_{\text {maks }}<\mathrm{L}_{\text {tabel }}$, yaitu $0.1243<0.234$; oleh karena itu data berdistribusi normal.

Uji Normalitas Sebaran Data Tes awal Skor Kemampuan Berpikir Kritis Siswa Kelas Kontrol (IX $\left.{ }_{B}\right)$ diperoleh:
a. $\quad \mathrm{L}_{\text {maks }}=0.16127$
b. Menentukan luas tabel Lilliefors $\left(\mathrm{L}_{\text {tabel }}\right), \mathrm{L}_{\text {tabel }}=\mathrm{L}_{0,05}\left(\mathrm{n}_{2}-1\right)=\mathrm{L}_{0,05}(13)$
$\mathrm{L}_{0.05}(13)=0.234$
c. $\mathrm{L}_{\text {maks }}<\mathrm{L}_{\text {tabel }}$, yaitu $0.16127<0.234$; oleh karena itu data berdistribusi normal.

Setelah diketahui sebaran data tes awal kelas ekperimen dan kelas kontol berdistribusi normal, maka di lanjutkan dengan uji homogenitas varians tes awal.

\section{Uji Homogenitas Varians Tes Awal}

Pengujian homogenitas dilakukan untuk menguji homogenitas varians data yang akan dianalisis antara kelas eksperimen dan kelas kontrol. Menurut (Sundayana, 2010) pasangan hipotesis yang akan diuji dalam pengujian homogenitas adalah sebagai berikut:

$H_{O}: \sigma_{1}^{2}={\sigma_{2}}^{2}$ (kedua varians homogen)

$H_{1}:{\sigma_{1}}^{2} \neq{\sigma_{2}}^{2}$ (kedua varians tidak homogen) 
Penerapan Model Pembelajaran Investigasi Kelompok Melalui Media Domino Matematika untuk Meningkatkan Kemampuan Berpikir Kritis Siswa, Cut Yuniza Eviyanti, Lia Rista, Siti Hadijah

Pengujian ini adalah uji dua pihak, dikarenakan berupa penelitian yang memerlukan perbandingan antara dua keadaan atau dua populasi. Maka kriteria pengujian : "Terima $\mathrm{H}_{0} \mathrm{jika} F<\mathrm{F}_{\mathrm{a}}\left(\mathrm{dk} \mathrm{n}_{\text {varians besar }}\right.$ -

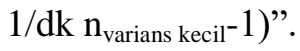

Berdasarkan perhitungan sebelumnya, diperoleh varians tes awal dari masing-masing kelompok $s_{1}{ }^{2}=$ 33.57 (varians kelas eksperimen) dan $s_{2}{ }^{2}=19.57$ (varians kelas kontrol). Untuk menguji homogenitas sampel digunakan persamaan sebagai berikut:

$$
F=\frac{\text { Varians besar }}{\text { Varians kecil }}
$$

$\mathrm{F}=1.72$

F Dari tabel distribusi diperoleh:

$\left(\mathrm{dk} \mathrm{n}_{\text {varians besar }}-1 / \mathrm{dk} \mathrm{n}_{\text {varians kecil }}-1\right)=\mathrm{F}_{0.05}(14-1 / 14-1)$

$$
=\mathrm{F}_{0.05}(13 / 13)=2.57
$$

Jadi $\mathrm{F}_{\text {hitung }}=1.72$ dan $\mathrm{F}_{\text {tabel }}=2.57$, jelas bahwa $\mathrm{F}_{\text {hitung }}<\mathrm{F}_{\text {tabel }}$ maka $\mathrm{H}_{0}$ diterima dan dapat disimpulkan bahwa kedua varians homogen untuk data pre-test.

\section{Perhitungan nilai $N$-Gain dari skor pre-test dan post-test}

Membandingkan skor pre-test dan post-test dilakukan untuk mencari nilai peningkatan (gain) yang terjadi sesudah pembelajaran pada masing-masing kelompok yang dihitung dengan rumus gain ternormalisasi ( $N$-Gain), yaitu seperti yang telah dijelaskan sebelumnya sehingga diperoleh data skor $N$-Gain.

Nilai $N$-Gain tiap kelas dihitung nilai rata-ratanya sehingga diperoleh nilai rata-rata tiap kelas. Dapat dilihat bahwa rata-rata $N$-Gain skor kemampuan berpikir kritis siswa di kelas eksperimen lebih besar dari pada siswa di kelas kontrol. Hal ini menunjukkan bahwa peningkatan kemampuan berpikir kritis siswa kelas eksperimen lebih baik dari pada kelas konvensional. Rata-rata $N$-Gain kelas kontrol yang bernilai 0.535 masuk ke dalam peningkatan kategori "sedang" dan kelas eksperimen yang bernilai 0.685 atau 0.7 masuk ke dalam peningkatan kategori "tinggi" sesuai dengan kriteria $\mathrm{N}$-Gain.

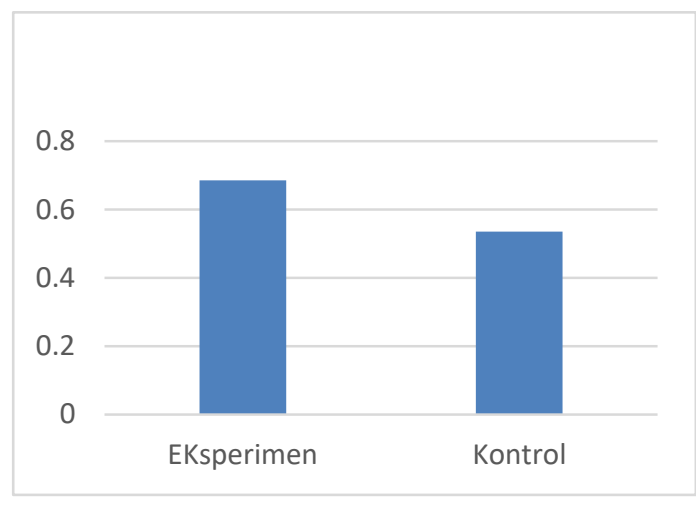

Gambar 3. Rata-rata N-Gain kelas eksperimen dan kelas kontrol. 
Dari hasil perhitungan diperoleh nilai varians kelas eksperimen $=0.055$ dan nilai simpangan baku kelas eksperimen $=0.23$. Sedangkan hasil perhitungan nilai varians kelas kontrol $=0.0829$ dan nilai simpangan baku kelas kontrol $=0.29$

\section{Uji Normalitas Sebaran Data N-Gain.}

Uji normalitas sebaran data bertujuan untuk mengetahui apakah data yang berupa $\mathrm{N}$-Gain skor kemampuan berpikir kritis dari masing-masing kelompok dalam penelitian ini berasal dari populasi berdistribusi normal atau tidak. Penulis menggunakan Uji Lilliefors karena data yang diperoleh tidak disajikan dalam bentuk interval.

Tabel 2.

Uji Normalitas N-Gain Skor Kemampuan Berpikir Kritis Siswa Kelas Eksperimen $\left(I_{A}\right)$

\begin{tabular}{|c|c|c|c|c|c|c|}
\hline$x_{i}$ & $f_{i}$ & $f_{\text {kum }}$ & $z_{i}$ & Luas $z_{i}$ & $\mathrm{~S}\left(z_{i}\right)$ & $\mid$ Luas zi-S $\left(z_{i}\right) \mid$ \\
\hline 0.26 & 1 & 1 & -1.85 & 0.0322 & 0.071 & 0.039 \\
\hline 0.36 & 1 & 2 & -1.41 & 0.0793 & 0.143 & 0.064 \\
\hline 0.43 & 1 & 3 & -1.11 & 0.1335 & 0.214 & 0.081 \\
\hline 0.5 & 1 & 4 & -0.8 & 0.2119 & 0.286 & 0.074 \\
\hline 0.58 & 1 & 5 & -0.46 & 0.3228 & 0.357 & 0.034 \\
\hline 0.61 & 1 & 6 & -0.33 & 0.3707 & 0.429 & 0.058 \\
\hline 0.67 & 1 & 7 & -0.07 & 0.4721 & 0.5 & 0.028 \\
\hline 0.71 & 1 & 8 & 0.109 & 0.5438 & 0.571 & 0.028 \\
\hline 0.86 & 1 & 9 & 0.761 & 0.7764 & 0.643 & 0.1335 \\
\hline 0.89 & 1 & 10 & 0.891 & 0.8188 & 0.714 & 0.1045 \\
\hline 0.91 & 1 & 11 & 0.978 & 0.8865 & 0.786 & 0.1008 \\
\hline 0.92 & 1 & 12 & 1.022 & 0.8461 & 0.857 & 0.011 \\
\hline 0.93 & 1 & 13 & 1.065 & 0.8554 & 0.929 & 0.073 \\
\hline 0.96 & 1 & 14 & 1.196 & 0.8849 & 1 & 0.115 \\
\hline
\end{tabular}

Berdasarkan tabel 2, data di atas diperoleh dengan perhitungan sebagai berikut:

a. $\mathrm{L}_{\text {maks }}=0.1335$

b. Menentukan luas tabel Lilliefors $\left(\mathrm{L}_{\text {tabel }}\right), \mathrm{L}_{\text {tabel }}=\mathrm{L}_{0,05}\left(\mathrm{n}_{1}-1\right)=\mathrm{L}_{0,05}(13)=0.234$

c. $\mathrm{L}_{\text {maks }}<\mathrm{L}_{\text {tabel, }}$, yaitu $0.1335<0.234$; oleh karena itu data berdistribusi normal.

\section{Tabel 3.}

Uji Normalitas N-Gain Skor Kemampuan Berpikir Kritis Siswa Kelas Kontrol (IX $)_{B}$.

\begin{tabular}{|c|c|c|c|c|c|c|}
\hline$x_{i}$ & $f_{i}$ & $f_{\text {kum }}$ & $z_{i}$ & Luas $z_{i}$ & $\mathrm{~S}\left(z_{i}\right)$ & $\mid$ Luas $z_{i}-\mathrm{S}\left(z_{i}\right) \mid$ \\
\hline 0.04 & 1 & 1 & -1.71 & 0.0436 & 0.071 & 0.027 \\
\hline 0.06 & 1 & 2 & -1.64 & 0.0505 & 0.143 & 0.093 \\
\hline 0.12 & 1 & 3 & -1.43 & 0.0764 & 0.214 & 0.138 \\
\hline 0.37 & 1 & 4 & -0.57 & 0.2843 & 0.286 & 0.002 \\
\hline 0.46 & 1 & 5 & -0.26 & 0.3974 & 0.357 & 0.0404 \\
\hline
\end{tabular}


Penerapan Model Pembelajaran Investigasi Kelompok Melalui Media Domino Matematika untuk Meningkatkan Kemampuan Berpikir Kritis Siswa, Cut Yuniza Eviyanti, Lia Rista, Siti Hadijah

\begin{tabular}{|c|c|c|c|c|c|c|}
0.52 & 1 & 6 & -0.05 & 0.4801 & 0.429 & 0.0511 \\
\hline 0.58 & 1 & 7 & 0.155 & 0.5636 & 0.5 & 0.0636 \\
\hline 0.62 & 1 & 8 & 0.293 & 0.6141 & 0.571 & 0.0431 \\
\hline 0.72 & 1 & 9 & 0.638 & 0.7389 & 0.643 & 0.0959 \\
\hline 0.76 & 1 & 10 & 0.776 & 0.7794 & 0.714 & 0.0654 \\
\hline 0.77 & 1 & 11 & 0.81 & 0.7910 & 0.786 & 0.005 \\
\hline 0.79 & 1 & 12 & 0.879 & 0.8078 & 0.857 & 0.049 \\
\hline 0.81 & 1 & 13 & 0.948 & 0.8289 & 0.929 & 0.1 \\
\hline 0.87 & 1 & 14 & 1.155 & 0.877 & 1 & 0.123 \\
\hline
\end{tabular}

Berdasarkan tabel 3, data di atas diperoleh dengan perhitungan sebagai berikut:

a. $\mathrm{L}_{\text {maks }}=0.123$

b. Menentukan luas tabel Lilliefors $\left(\mathrm{L}_{\text {tabel }}\right), \mathrm{L}_{\text {tabel }}=\mathrm{L}_{0,05}\left(\mathrm{n}_{2}-1\right)=\mathrm{L}_{0,05}(13)$

$\mathrm{L}_{0.05}(13)=0.234$

c. $\mathrm{L}_{\text {maks }}<\mathrm{L}_{\text {tabel }}$, yaitu $0.123<0.234$; oleh karena itu data berdistribusi normal.

\section{Uji Homogenitas Varians Data $N$-Gain}

Pengujian homogenitas dilakukan untuk menguji homogenitas varians data yang akan dianalisis antara kelas eksperimen dan kelas kontrol. Menurut (Sundayana, 2010) pasangan hipotesis yang akan diuji dalam pengujian homogenitas adalah sebagai berikut:

$H_{o}: \sigma_{1}^{2}=\sigma_{2}^{2}$ (kedua varians homogen)

$H_{1}: \sigma_{1}^{2} \neq \sigma_{2}^{2}$ (kedua varians tidak homogen)

Pengujian ini adalah uji dua pihak, dikarenakan berupa penelitian yang memerlukan perbandingan antara dua keadaan atau dua populasi. Maka kriteria pengujian : "Terima $\mathrm{H}_{0}$ jika $\mathrm{F}<\mathrm{F}_{\mathrm{a}}\left(\mathrm{dk} \mathrm{n}_{\text {varians besar }}\right.$ $1 / \mathrm{dk} \mathrm{n}_{\text {varians kecil-1)". }}{ }^{-1}$.

Berdasarkan perhitungan sebelumnya, diperoleh varians $\mathrm{N}$-gain dari masing-masing kelompok $s_{1}{ }^{2}=0.055$ (varians kelas eksperimen) dan $s_{2}{ }^{2}=0.0829$ (varians kelas kontrol). Untuk menguji homogenitas sampel digunakan persamaan sebagai berikut:

$$
F=\frac{\text { Varians besar }}{\text { Varians kecil }}
$$

$F=1.5$

F Dari tabel distribusi diperoleh:

$$
\begin{aligned}
\left(\mathrm{dk} \mathrm{n}_{\text {varians besar }}-1 / \mathrm{dk}_{\text {varians kecil }}-1\right) & =\mathrm{F}_{0.05}(14-1 / 14-1) \\
& =\mathrm{F}_{0.05}(13 / 13)=2.57
\end{aligned}
$$

Jadi $F_{\text {hitung }}=1.5$ dan $F_{\text {tabel }}=2.57$, jelas bahwa $F_{\text {hitung }}<\mathrm{F}_{\text {tabel }}$ maka $\mathrm{H}_{0}$ diterima dan dapat disimpulkan bahwa kedua kelompok data mempunyai variansi yang homogen. 


\section{Pengujian Hipotesis Data $N$-Gain}

Pada pengujian hipotesis ini, yang akan dilakukan adalah menghitung atau membandingkan kedua hasil perhitungan yang telah diperoleh sebelumnya. Adapun nilai rata-rata dan varians $\mathrm{N}$-Gain yang diperoleh ialah:

$\begin{array}{llll}\overline{\mathrm{x}_{1}}=\mathbf{0 . 6 8 5} & \mathrm{s}_{1}{ }^{2}=0.055 & \mathrm{~s}_{1}=0.23 & \mathrm{n}_{1}=14 \\ \overline{\mathrm{x}_{2}}=\mathbf{0 . 5 3 5} & \mathrm{s}_{2}{ }^{2}=0.0829 & \mathrm{~s}_{2}=0.29 & \mathrm{n}_{2}=14\end{array}$

Dengan demikian untuk mencari varians gabungan $\left(\mathrm{s}^{2}\right)$ digunakan persamaan sebagai berikut :

$\mathrm{s}^{2}=\frac{\left(\mathrm{n}_{1}-1\right) \mathrm{s}_{1}^{2}+\left(\mathrm{n}_{2}-1\right) \mathrm{s}_{2}^{2}}{\mathrm{n}_{1}+\mathrm{n}_{2}-2}$

$\mathrm{S}^{2}=0.06895$

$\mathrm{s}=0.26$

Untuk nilai $\mathrm{s}=0.26$ diperoleh nilai $\mathrm{t}$ digunakan persamaan (Sudjana, 2010) sebagai berikut:

$\mathrm{t}=\frac{\bar{x}_{1}-\bar{x}_{2}}{\mathrm{~S} \sqrt{\frac{1}{\mathrm{n}_{1}}+\frac{1}{\mathrm{n}_{2}}}}$

$\mathrm{t}=4.05$

Pada taraf signifikan $\alpha=0,05$ dan derajat kebebasan $\mathrm{dk}=26$, maka $\mathrm{t}_{\text {tabel }}=\mathrm{t}_{(1-\alpha)\left(\mathrm{n}_{1}+\mathrm{n}_{2}-2\right)}=\mathrm{t}_{(0.95)(26)} .=$ 1,71

Kriteria pengujian adalah tolak $\mathrm{H}_{\mathrm{o}}$ jika $\mathrm{t}_{\text {Hitung }}>\mathrm{t}_{\text {Tabel }}$, untuk harga $\mathrm{t}$ lainnya $\mathrm{H}_{\mathrm{o}}$ diterima. Berdasarkan hasil perhitungan diatas diperoleh $t_{\text {hitung }}=4.05$ dan $t_{\text {tabel }}=1.71$ atau $t_{\text {Hitung }}>t_{\text {Tabel }}$. Dengan demikian $\mathrm{H}_{\mathrm{o}}$ ditolak pada taraf signifikan $\alpha=0,05$. Berarti dapat disimpulkan bahwa peningkatan kemampuan berpikir kritis siswa melalui penerapan model pembelajaran investigasi kelompok secara daring melalui media domino matematika lebih baik dari pada peningkatan kemampuan berpikir kritis siswa melalui penerapan pembelajaran konvensional di kelas IX SMP Negeri 1 Lhokseumawe. Hal ini sesuai dengan penelitian terdahulu (Haridi, 2018) yang menyimpulkan bahwa ada peningkatan hasil belajar matematika melalui model pembelajaran investigasi kelompok dan penelitian terdahulu (Lestari et al., 2019) yang menyimpulkan bahwa penerapan model pembelajaran Group Investigation dapat meningkatkan kemampuan berpikir kritis peserta didik kelas XI pada materi lingkaran. Serta penelitian terdahulu (Rifa'i \& Sartika, 2018) yang menyimpulkan bahwa hasil belajar matematis siswa yang memperoleh pembelajaran investigasi kelompok lebih baik daripada yang memperoleh model pembelajaran konvensional.

\section{KESIMPULAN}

Berdasarkan hasil analisis data penelitian, maka dapat disimpulkan bahwa: Peningkatan kemampuan berpikir kritis siswa yang mendapat penerapan dengan model pembelajaran investigasi kelompok melalui media domino matematika lebih baik dibandingkan peningkatan kemampuan berpikir kritis siswa yang mendapat pembelajaran konvensional pada materi bilangan berpangkat dan 
Penerapan Model Pembelajaran Investigasi Kelompok Melalui Media Domino Matematika untuk Meningkatkan

bentuk akar di kelas IX SMP Negeri 1 Lhokseumawe.

\section{DAFTAR PUSTAKA}

Anggraini, L., Siroj, R. A., \& Ilma, R. (2010). Penerapan Model Pembelajaran Investigasi Kelompok Untuk Meningkatkan Kemampuan Pemecahan Masalah Matematika Siswa Kelas Viii-4 Smp Negeri 27 Palembang. Jurnal Pendidikan Matematika, 4(1). https://doi.org/10.22342/jpm.4.1.309.

Arinda, Y., Wilujeng, I., \& Kuswanto, H. (2019). The Application Group Investigation (GI) Learning Model assisted Phet to Facilitate Student Scientific Work Skills. International Journal of Educational Research Review, 4(2), 254-261. https://doi.org/10.24331/ijere.518069

Eviyanti, C. . (2018). Perbedaan Peningkatan Kemampuan Representasi Matematis dan Self Confidence Siswa Pada Pembelajaran Berbasis Masalah dan Pembelajaran Biasa. Judika Education, 1(2).

Haridi. (2018). Penerapan Pembelajaran Group Investigation Untuk Meningkatkan Hasil Belajar Matematika Siswa Kelas X Ipa 1 Man 2 Banyuwangi. AXIOM: Jurnal Pendidikan Dan Matematika, 7(2). https://doi.org/10.30821/axiom.v7i2.2891

Lestari, E., Cahyono, H., \& Awaluddin, A. (2019). Penerapan model pembelajaran group investigation pada materi lingkaran untuk meningkatkan kemampuan berpikir kritis. Jurnal Math Educator Nusantara: Wahana Publikasi Karya Tulis Ilmiah Di Bidang Pendidikan Matematika, 5(2), 124-139. https://doi.org/10.29407/jmen.v5i2.12814

Lloyd, M. Bahr, N. (2010). Thinking Critically about Critical Thinking in Higher Education. International Journal for the Scholarship of Teaching and Learning, 4(2). https://doi.org/10.20429/ijsotl.2010.040209

Rifa'i, R., \& Sartika, N. S. (2018). Penerapan Pembelajaran Investigasi Kelompok terhadap Hasil Belajar Matematis Siswa Sekolah Menengah Pertama. Jurnal Analisa, 4(1), 43-50. https://doi.org/10.15575/ja.v4i1.1960

Rusman. (2010). Mengembangkan Profesionalisme Guru. Rajawali Pers.

Sudjana. (2010). Metoda Statistika. Tarsito.

Sumarmi. (2012). Model-Model Pembelajaran Geografi. Aditya Media.

Sundayana, R. (2010). Statistika Penelitian Pendidikan. STKIP Garut Press.

Suprihatiningrum, J. (2013). Strategi Pembelajaran Teori dan Aplikasi. Ar-Ruzz Media. 
Suwarna, D. (2019). Kemampuan Berpikir Kritis Matematika. Cakrawala Mahakarya.

Wulandari, P., Mujib, M., \& Putra, F. G. (2016). Pengaruh Model Pembelajaran Investigasi Kelompok berbantuan Perangkat Lunak Maple terhadap Kemampuan Pemecahan Masalah Matematis. AlJabar: Jurnal Pendidikan Matematika, 7(1), 101-106. http://ejournal.radenintan.ac.id/index.php/al-jabar/article/view/134/124 